\title{
Analisis Kelayakan Usaha Industri Rumput Laut Bagi Industri Kecil Menengah di Kecamatan Moro Kabupaten Karimun Provinsi Kepulauan Riau
}

\author{
Fatahurrazak \\ Fakultas Ekonomi,Universitas Maritim Raja Ali Haji, Tanjungpinang, Kepulauan Riau, Indonesia.
}

\begin{abstract}
ABSTRAK : Penelitian ini bertujuan untuk melihak kelayakan bisnis pada Pembangunan Kompleks Industri Maritim (Sentra Industri) Pengolahan Rumput Laut di Kecamatan Moro, Kabupaten Karimun Provinsi Kepulauan Riau dimaksudkan untuk memacu pertumbuhan industri daerah dengan keterlibatan para pihak berkepentingan termasuk pengusaha industri kecil dan menengah sehingga memberikan manfaat bagi berbagai pihak. Penyusunan pola pengembangan sentra menggunakan konsepsi sebagaimana diatur dalam perundang-undangan diharapkan menghadirkan sentra dengan prinsip lingkungan bersih, industri hijau dengan memperhatikan sanitasi dan higienitas, keseimbangan dengan ruang terbuka dan efektivitas pemanfaatan ruang dan biaya. Metodologi dalam menghasilkan keluaran tersebut di atas dilakukan dengan mempelajari data primer dan data skunder yang didapat langsung dari lokasi dan pemerintah daerah Kabupaten Karimun. dokumen sekunder berupa RPJPD - RPJMD RTRW Kabupaten Karimun, rencana strategi terkait pengembangan industri, infrastruktur, peran institusi maupun stakeholder terkait dalam pengembangan Sentra Industri pengolahan rumput laut, dan kebijakan ekonomi daerah yang relevan. Pengumpulan data dan informasi pula dilakukan dengan observasi langsung pada lokasi, wawancara, dan kuisioner. Alat analisis yang digunakan adalah Net Present Value dengan discount factor 15\%, Net B/C, Internal Rate of Return, dan Payback Period. Dan hasilnya adalah NPV > 0, layak dilaksanakan, Net B/C > 1, layak dilaksanakan, IRR > discount factor 15\%, layak dilaksanakan, dan Payback Period 4,18 tahun.
\end{abstract}

Kata Kunci: Rumput laut, E.Cottonii, ATC Chips, Sentra Industri, Moro Collagen

Email Address: faturajafatur@ gmail.com

\section{Pendahuluan}

Salah satu tujuan pertumbuhan ekonomi adalah adanya pemerataan ekonomi di beberbagai wilayah di Indonesia serta tercapainya pembangunan yang berkelanjutan (sustainable development). Tujuan tersebut hanya dapat dicapai dengan pengelolaan sumberdaya alam yang menjamin daya dukung lingkungan dan pelestarian alam. Sejauh ini sumberdaya alam dikelola dengan tidak terkendali yang mengakibatkan kerusakan lingkungan serta mengganggu kelestarian alam yang akhirnya mengurangi daya dukung dalam melaksanakan pembangunan yang berkelanjutan. Kebijakan pembangunan berkelanjutan perlu melihat potensi sumber daya bahan baku yang dapat diperbaharui (renewable resource) agar industri yang dibangun dapat bersifat jangka panjang, menjaga keseimbangan alam dan tentunya menciptakan ekonomi yang kuat di tingkat regional maupun nasional. Salah satu sentra industri yang sangat berkembang dan memiliki potensi yang besar dewasa ini adalah rumput laut (seaweed). Rumput laut (seaweed) merupakan salah satu komoditi yang potensial dan dapat menjadi andalan bagi upaya pengembangan industri kecil dan menengah yang sering disebut sebagai IKM. Ini terjadi karena rumput laut sangat banyak digunakan oleh manusia, baik melalui pengolahan sederhana yang langsung dikonsumsi maupun melalui pengolahan yang lebih kompleks untuk dijadikan barang setengah jadi dan diolah lebih lanjut oleh industri hilir menjadi barang jadi yang dapat digunakan (dikonsumsi) langsung, seperti produk farmasi, kosmetik dan pangan serta produk lainnya yang lebih dari 500 varian turunan atau End product.

Hal ini juga tidak terlepas dari Nawacita Presiden yang menyatakan bahwa Laut adalah Masa Depan Peradaban Bangsa. Hal ini menunjukkan bahwa laut tidak boleh dipunggungi, sudah saatnya bangsa Indonesia melihat laut sebagai sumber kehidupan manusia. 
Oleh sebab itu pembangunan kelautan dan perikanan harus dilakukan oleh seluruh pemangku kepentingan untuk mengubah suatu keadaan menjadi keadaan yang lebih baik dengan memanfaatkan sumberdaya kelautan dan perikanan secara optimal, efisien, efektif, dan akuntabel, dengan tujuan akhir untuk meningkatkan kesejahteraan masyarakat secara berkelanjutan.

Indonesia memiliki potensi pengembangan rumput laut yang cukup besar, $85 \%$ rumput laut basah Dunia berasal dari Indonesia, sedangkan sisanya dipasok dari Philipina (15\%). Rumput laut merupakan salah satu hasil laut yang telah diperdagangkan secara luas dalam perdagangan internasional. Secara umum atau nasional hasil rumput laut Indonesia di Ekspor ke China, ini dilakukan mengingat belum adanya industrialisasi rumput laut disentra sentra penghasil rumput laut. Belum adanya industrialisasi rumput laut berskala IKM disebabkan terbatasnya sumberdaya manusia yang memiliki skill di bidang budidaya rumput laut, mesin/peralatan pengolahan rumput laut yang masih tradisional dan faktor pemasaran yang belum menjanjikan.

Untuk mendukung terciptanya nilai tambah dari produk rumput laut tersebut maka dipandang perlu sentra industrialisasi atau pendirian pabrik pengolahan rumput laut yang berskala IKM di Indonesia, khususnya provinsi kepulauan Riau yang memiliki luas laut $96 \%$ dari total wilayah territorial. Salah satu kabupaten di provinsi Kepulauan Riau yang yang sudah mengembangkan industri pengolahan rumput laut dalam skala kecil adalah kabupaten Karimun. Kabupaten karimun memiliki potensi untuk budi daya rumput laut sebagai bahan baku utama dalam industri pengolahan rumput laut. Masyarakat pesisir di Kecamatan Moro kabupaten karimun sudah membudidayakan rumput laut, yang didukung oleh beberapa masyarakat di sekitar kecamatan moro seperti masyarakat Pulau Jaga, Tanjung Semukul, Desa Sugie, Pulau Bahan Pulau Jang mulai mengembangkan bibit rumput laut jenis Euchema cottonii dan E. spinossum. pada dimusim selatan, pertumbuhanya sangat optimal. Namun, jumlahnya masih terbatas karena tidak didukung oleh kemampuan keuangan dan sarana yang cukup untuk meningkatkan jumlah produksi dan jumlah kelompok petaninya (Tanjungpinangpos). Budidaya rumput laut, sebagian besar dilakukan para petani Moro yang mencapai 1.230 orang di atas lahan seluas 4.500 hektare dengan kualitas panen bermutu tinggi (antaranews).

Sebelum pendirian sentra industri rumput laut berskala IKM agar layak dilakukan di kecamatan Moro , maka tentu harus dibuat rencana induk pembangunan (master plan), studi kelayakan (feasibility study), dan rencana pengembangan bisnis (business plan) untuk melihat potensi dan pola pengembangan sentra industri rumput laut dalam berbagai aspek. Hal ini agar diperoleh suatu gambaran atau masukan bagi pemerintah dan instansi terkait dalam pengambilan keputusan dan kebijakan pengembangan sentra industri kecil dan menengah pengolahan rumput laut ke depan agar dapat memperkuat dan mempercepat pertumbuhan ekonomi di wilayah Kecamatan Moro Kabupaten Karimun Provinsi Kepulauan Riau.

\section{Maksud dan Tujuan}

Penyusunan Pembangunan Komplek Industri Maritim (Sentra Industri) Pengolahan Rumput Laut di Kabupaten Karimun Provinsi Kepulauan Riau dimaksudkan untuk memacu pertumbuhan industri daerah dengan keterlibatan para pihak berkepentingan termasuk pengusaha industri kecil dan menengah sehingga memberikan manfaat bagi berbagai pihak. Penyusunan pola pengembangan sentra menggunakan konsepsi sebagaimana diatur dalam perundang-undangan diharapkan menghadirkan sentra dengan prinsip lingkungan bersih, industri hijau dengan memperhatikan sanitasi dan higienitas, kesiembangan dengan ruang terbuka dan efektivitas pemanfaatan ruang dan biaya.

Tujuan penelitian ini adalah untuk melakukan analisis feasibility study Sentra IKM pengolahan Rumput laut di Kecamatan Moro Kabupaten Karimun, Provinsi Kepulauan Riau

\section{Kondisi Geografis}

Kabupaten Karimun merupakan bagian dari wilayah Provinsi Kepulauan Riau, yang berbatasan dengan Negara Singapore dan Negeri Jiran Malaysia, serta berdampingan dengan pusat pertumbuhan industri Batam dan Bintan. 
Kabupaten Karimun merupakan salah satu kabupaten baru di Provinsi Kepulauan Riau, yang berdasarkan UU RI No. 53 tahun 1999.

Adapun secara geografis Kabupaten Karimun terbentang antara $00^{\circ} 24^{\prime} 36^{\prime \prime} \mathrm{LU}$ sampai $01^{\circ} 13^{\prime} 12^{\prime \prime}$ LU dan $103^{\circ} 13^{\prime} 12^{\prime \prime}$ BT sampai $104^{\circ} 00^{\prime} 36^{\prime \prime} \mathrm{BT}$, tepat berada pada jalur pelayaran dan dekat dengan zona penerbangan internasional. Luas wilayah Kabupaten Karimun memiliki luas Secara keseluruhan mencapai $7.984 \mathrm{~km} 2$ dengan wilayah perairan yang lebih besar dibandingkan daratan. Luas wilayah perairan Kabupaten Karimun mencapai 80,91 persen dan luas daratannya hanya 19,09 persen dimana wilayah dengan luas terbesar adalah Kecamatan Moro $4.918 \mathrm{Km}^{2}$ yang terdiri dari luas daratan $932 \mathrm{Km}^{2}$ (93.157 Ha) dan luas lautan sekitar $3.987 \mathrm{Km}^{2}$ atau seluas $398.692 \mathrm{Ha}$, dengan demikian dapat dilihat bahwa Kabupaten Karimun di kelilingi oleh lautan, kabupaten karimun merupakan gugusan pulau besar dan kecil sejumlah 249 pulau, yang terdiri dari 54 pulau telah berpenduduk dan 195 pulau lainnya belum berpenghuni.

\section{Kependudukan}

Pada tahun 2011, jumlah penduduk Kabupaten Karimun mencapai216.146 jiwa, sedangkan pada tahun 2014 jumlahnya meningkat menjadi 223.117 jiwa. Dengan demikian selama tiga tahun terakhir telah terjadi peningkatan jumlah penduduk sebesar 6.971 jiwa atau 2.323 jiwa per tahun.

Meskipun jumlah penduduk Kabupaten Karimun terus menunjukkan perkembangan, namun secara laju pertumbuhan penduduk (LPP) ternyata justru menunjukkan tren yang menurun. Jika LPP pada tahun 2011 mencapai 1,69 persen, maka pada tahun 2014 nilainya hanya sebesar 1,01 persen. Dengan demikian selama empat tahun terakhir, LPP Kabupaten Karimun telah mengalami penurunan hampir 0,68 persen, dengan rata-rata LPP Kabupaten Karimun hanya berkisar 1,22 persen. Jumlah migrasi masuk di Kabupaten Karimun tahun 2014 sebesar 14.055 jiwa. Dari jumlah tersebut 6.662 orang merupakan penduduk laki-laki dan 7.393 merupakan penduduk perempuan. Dengan demikian rasio migrasi masuk antara penduduk perempuan terhadap laki-laki adalah sebesar 1,11

\section{Metode Penelitian}

\section{Pendekatan Studi}

Kegiatan Kajian Pembangunan Komplek Industri Maritim (Sentra Industri) Pengolahan Rumput Laut di Kabupaten Karimun Provinsi Kepulauan Riau ini mengkombinasikan pendekatan kuantitatif dan kualitatif. Pendekatan kuantitatif dimaksudkan untuk memberikan suatu pelaporan yang menggunakan basis data kuantitatif, sehingga target pencapaian yang akan diambil oleh para pihak yang akan menggunakan laporan kajian ini menjadi jelas, namun pendekatan kuantitatif yang dimaksud adalah terbatas pada statistika deskriptif yang terdiri dari ukuran-ukuran pemusatan data. Pendekatan kualitatif dimaksudkan untuk memberikan suatu pelaporan dengan penjelasan atau gambaran yang mendalam, sehingga para pihak yang akan menggunakan laporan ini dapat memahami permasalahan dan solusi yang ditawarkan secara utuh.

Setiap tujuan penelitian menggunakan pendekatan kuantitatif dan kualitatif yang sifatnya simultan, sehingga informasi yang disajikan di dalam dokumen ini berbasis data kuantitatif dan mendalam. Pendekatanpendekatan yang dimaksud adalah pendekatan adalah pendekatan top down-bottom up/participation planning, pendekatan manfaat eknomi ganda (multiplier effects approach), pendekatan sumberdaya (resources base approach), pendekatan manajemen interaksi dan pendekatan deskripsi mendalam (thick description approach).

Studi lapangan dimaksudkan untuk mengumpulkan data sekunder dan primer yang dibutuhkan dalam mengidentifikasi dan menginventarisasi pembangunan sentra industri rumput laut di Kabupaten Karimun yang telah ada, yang akan dihapus, yang akan disatukan, dan yang akan didirikan baru di lingkungan wilayah sentra industri. Studi lapangan juga dimaksudkan untuk memperoleh informasi yang akurat tentang kebutuhan sumberdaya manusia, sumberdaya 
fisikal, dan sumberdaya finansial dari sentra industri yang akan dibentuk. Verifikasi terhadap data sekunder yang diacu dalam kajian ini, yaitu yang diperoleh dari studi literatur, dokumen, dan informasi geografis, serta kajian-kajian sebelumnya, dilakukan pula pada tahapan studi lapangan ini.

\section{Pengumpulan Data}

Data dikumpulkan dengan teknik observasi, wawancara terstruktur, wawancara mendalam, diskusi, dan studi dokumen/literatur.

\section{Metode Analisis Data}

Data yang telah dikumpulkan selanjutnya dianalisis dengan menggunakan metode analisis feasibility study.

\section{Hasil dan Pembahasan Aspek Produksi}

Lokasi Pabrik di Kelurahan Moro, Kecamatan Moro, pada lahan pemerintah daerah seluas 8000 M2 , berada pada 103 42' 0" - 103 42' 3,6” BT- 0 46' 48”- 0 46' 1,2” LU. Lokasi berjarak sekitar 42,7 km. Letak pabrik di Kecamatan Moro agar dapat memanfaatkan bahan baku rumput laut yang di budidayakan masyarakat setempat seperti dari Pulau Jang, Pulau Bahan, Pulau Semukul dan di Pulau Semukul.

Kabupaten Karimun merupakan wilayah di Provinsi Kepulauan Riau yang memiliki persentase Industri Kecil dan Menengah (IKM) yang ke tiga tertinggi dibandingkan wilayah lainnya. Perbandingan persentase jumlah IKM di Kabupaten Karimun dengan wilayah lainnya di Provinsi Kepulauan Riau dapat dilihat pada Tabel berikut ini :

Berdasarkan dari presentase tersebut Kabupaten Karimun memeliki nilai presentase sebesar 14, 26\% atau sekitar 978 IKM jenis IKM yang ada di Kabupaten Karimun Di dominasi IKM pengolahan hasil perikanan. Komoditas unggulan dari hasil tangkapan nelayan di Kabupaten Karimun terdiri dari kelompok pelagis (ikan tongkol krai dan tenggiri), kelompok pelagis kecil (selar, ikan teri, kembung, tembang dan tetengkek), kelompok ikan demersal (kurau, bawal putih, manyung, kakap putih dan kuwe), kelompok ikan karang (kakap merah/bambangan, ekor kuning/pisang-pisang, kerapu karang, ikan baronang dan lencam), kelompok kustase (kepiting dan rajungan) dan kelompok moluska (cumi-cumi dan sotong).

Pengembangan industri rumput laut di Indonesia memiliki prospek yang cerah. Menurut Sudariastuty (2011) hal ini disebabkan oleh teknik budidaya rumput laut yang relatif mudah dikuasai oleh masyarakat, sehingga usaha tersebut dapat dilakukan secara masal. Dengan banyaknya rumput laut yang dihasilkan maka input untuk industri rumput laut nasional diharapkan dapat terpenuhi tanpa mengandalkan impor. Disamping itu permintaan terhadap

\begin{tabular}{|c|l|c|}
\hline No & Kabupaten/ Kota & \% IKM \\
\hline \hline 1 & Batam & 41,25 \\
\hline 2 & Bintan & $3,86 \%$ \\
\hline 3 & Karimun & $14,26 \%$ \\
\hline 4 & Tanjungpinang & $9,73 \%$ \\
\hline 5 & Natuna & $15,31 \%$ \\
\hline 6 & Anambas & $5,48 \%$ \\
\hline 7 & Lingga & $10,11 \%$ \\
\hline \hline & TOTAL & $\mathbf{1 0 0}$ \\
\hline
\end{tabular}

rumput laut dan produk olahannya baik di pasar domestik maupun internasional selalu menunju. Kabupaten Karimun peningkatan setiap tahunnya.

Dalam rangka menyokong pengembangan industri rumput laut nasional maka harus dilakukan langkah-langkah insentif oleh pihakpihak terkait. Sudariastuty (2011) menjelaskan bahwa dalam upaya peningkatan nilai tambah serta nilai jualnya, maka pengembangan usaha budidaya rumput laut harus diikuti dengan pengembangan industri pengolahannya seperti misalnya pengembangan teknologi pengolahan rumput laut menjadi berbagai jenis olahan yang berbasis rumput laut harus dikembangkan selaras dengan perkembangan budidayanya. Salah satu upaya pengembangan industri rumput laut adalah dengan inovasi hijau dalam industri pengolahan rumput laut, khususnya pada Alkali Treated Cottonii (ATC). 
Rumput laut merupakan produk hasil perikanan budidaya yang memiliki beberapa produk turunan yang dapat dimanfaatkan. McHugh (2003) menyebutkan bahwa terdapat tiga produk turunan dari rumput laut, diantaranya adalah: 1) Agar-agar, merupakan hidrokoloid rumput laut yang memiliki kekuatan gel yang sangat kuat yang dihasilkan dari proses ekstraksi rumput laut kelas Rhodophyceae terutama genus Gracilaria dan Gelidium. Fungsi utama agarose adalah untuk mencegah terjadinya dehidrasi dari makanan yang ditambahkan. 2) Keraginan, adalah hidrokoloid yang merupakan senyawa polisakarida rantai panjang yang diekstrak dari rumput laut jenis karagenofit seperti Eucheuma $s p$, Hypnea sp. Keraginan dibedakan menjadi tiga macam yaitu iota keraginan, kappa keraginan dan lambda keraginan, ketiganya berbeda dalam sifat gel. Kappa keraginan menghasilkan gel yang kuat, sedangkan iota keraginan membentuk gel yang halus dan mudah dibentuk. 3) Alginat, merupakan hidrokoloid yang diekstrak dari alga coklat atau Phaeophyceae yang merupakan genus Sargassum dan Turbinaria. Alginat menjadi penting karena penggunaannya yang luas dalam industri karena sifatnya sebagai pembentuk gel, bahan pengemulsi, dll.

Menurut data Kementerian Kelautan dan Perikanan pada tahun 2017 Provinsi Kepulauan Riau memiliki jumlah produksi rumput laut hasil budidaya sebesar 12.545 Ton. Jumlah Produksi tersebut tentunya terbilang kecil jika dilihat dari letak geografis dibandingkan provinsi Kepulauan lainnya. Untuk Produksi Rumput Laut ditingkat Kabupaten. Kabupaten Karimun memilki jumlah produksi 145 ton/tahun. Seharusnya Kabupaten Karimun dapat memproduksi rumput laut sebesar 107.500 ton/tahun dengan luas area budidaya sebesar 210 Ha. Rencana pengembangan industri rumput laut di Kabupaten Karimun seperti pada gambar berikut :

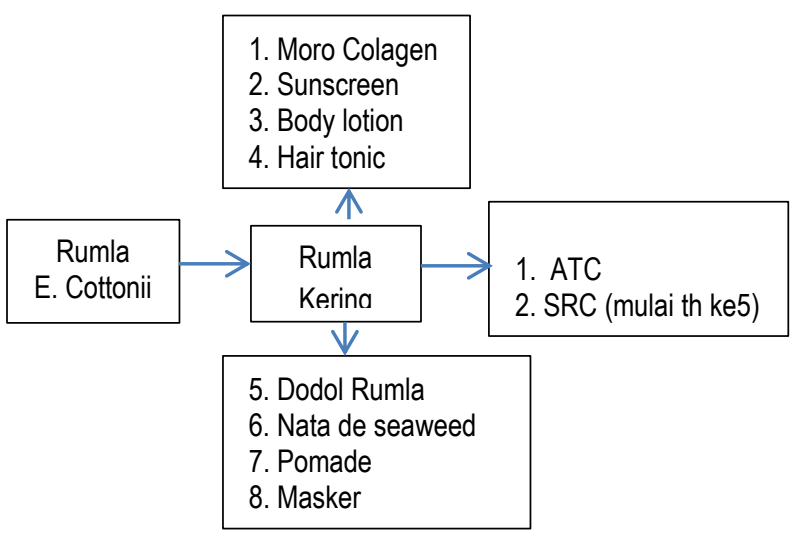

Berdasarkan analisa pohon industri hasil laut Kabupaten Karimun, terdapat beberapa proses pengolahan rumput laut yang dapat dikembangkan oleh masyarakat seperti produk ATC, dodol, nata de seaweed, hair tonic, body lotion, sunscreen,pomade, moro collagen dan masker rumput laut. Selanjutnya jika jumlah rumput laut melimpah maka dapat dikembangkan kearah Alkali Treated Cottonii, Semi Refined Carraginan dan Refined Carraginan.

Jenis Rumput Laut yang dapat digunakan yaitu Rumput laut E. cottonii dan E.spinosum. Jenis rumput laut E. Cottonii telah banyak di budidayakan di Kecamatan Moro Kabupaten Karimun sedangkan rumput laut E.spinosum untuk saat ini masyarakat mengumpulkannya dari alam. IKM yang sudah berjalan memanfaatkan rumput laut sebagai bahan baku ada lah moro collagen yang memproduksi suplemen kesehatan, sedangkan produk ATC, dodol, nata de seaweed, hair tonic, body lotion, sunscreen,pomade dan masker rumput laut bagian dari pengembangan produk rumput laut untuk menjadi salah satu produk yang diunggulkan dan dikembangkan pada sentra IKM bila telah kembali diproduksi masal oleh masyarakat.

\section{Aspek Pemasaran}

Kunci untuk menganalisis rantai nilai adalah dengan memahami kegiatan pada setiap pelaku usaha dan kemudian mengelola kegiatan tersebut agar produk menjadi lebih baik sehingga lebih kompetitif dan berdaya saing. Selama ini, usaha rumput laut mulai proses produksi hingga pemasaran memiliki rantai yang panjang sehingga harga jual akhir yang tinggi. Hal ini menyebabkan produk tidak kompetitif dan tidak berdaya saing. Analisis rantai nilai merupakan sarana untuk memeriksa setiap proses yang dilakukan dalam sebuah sistem untuk menciptakan produk dan mengidentifikasi kegiatan dari setiap pelaku usaha. 
Rumput laut yang diproduksi oleh pembudidaya umumnya dijual dalam bentuk kering. pembudidaya melakukan pengeringan terhadap rumput laut dengan dijemur di bawah matahari sehingga menghasilkan rendemen sekitar 1/6 dari berat awal. Penjualan dilakukan ke pedagang pengumpul yang ada di sekitarnya (Kecamatan Moro). Pedagang pengumpul ini umumnya yang mengambil atau menjemput rumput laut ke pembudidaya dengan menggunakan motor yang kemudian ditampung di sebuah gudang.

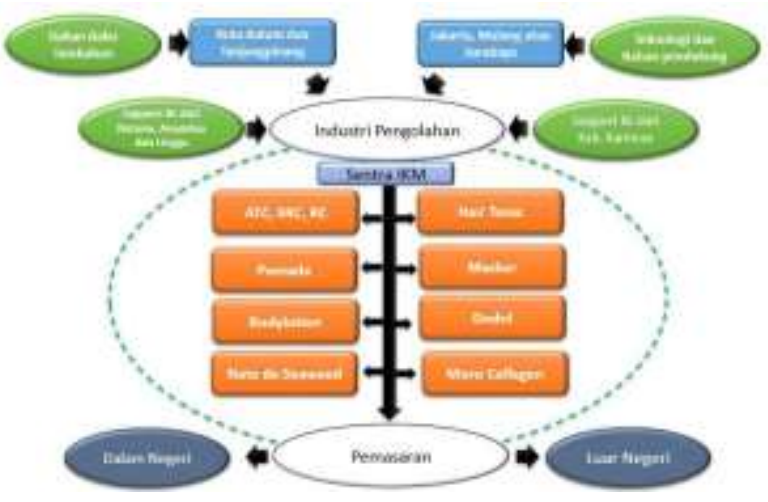

Distribusi dan Pemasaran Produk

\section{Aspek Produksi}

Fasilitas produksi mencakup, hal-hal sebagai berikut: Pengadaan air bersih. Air bersih dipompa dari mata air di perbukitan di belakang pabrik. Pengadaan air bersih merupakan hal yang paling genting dalam produksi Cottonii Chips; Gudang bahan baku, bahan kimia, dan produk. Gudang bahan baku digunakan juga untuk membersihkan bahan baku dari kontaminan; Bak perendamanan; Tungku perebusan; Bak pencucian yang dilengkapi dengan dua kincir untuk menggerakkan air, sehigga menciptakan situasi seperti air mengalir; Lantai jemur; Pemilahan logam dengan alat pemisah magnetik. Pemotongan; Ruang pencampuran Cottonii Chips yang sudah dipotong. Laboratorium; Kren (crane), yang berfungsi untuk memindahkan barang dari tempat perendaman ke perebusan serta ke pencucian. Kapasitas crane adalah 3 ton (dengan catatan 1 batch adalah 1 ton, maka setelah perendaman berat bahan bisa mencapai lebih dari 2 ton).
Adapun proses produksi ATC adalah sebagai betikut :

(1) Persiapan : yang terdiri dari Pekerjaan: Penimbangan. Berat bahan baku yang akan diseleksi adalah 1.000- $2.000 \mathrm{~kg}$. Seleksi : Balian baku harus bebas dari katoran (Varietas lain, pasir dan batu, plastik. dan sebagainya). Hasil yang sudah diseleksi, ditampung pada container plastik)

(2) Perendaman : Contaiiner plastik berisi bahan baku yang sudah terseleksi, dibawa ke tempat perendaman dengan menggunakan lori dorong. Container itu diletakkan di sana menjelang proses perendaman. Perendaman dilakukan pada keranjang perendaman berkapasitas $1.000 \mathrm{~kg}$. Perendaman ini terutama dimaksudkan untuk menghilangkan garam dan debu.

(3) Perebusan : Larutan perebusan dicampur dengan $\mathrm{KOH}$ sebanyak $8 \%(80 \mathrm{~kg})$ dan $\mathrm{KCI}$ sebanyak $0,2 \%(2 \mathrm{~kg})$.Kalium berfungsi unruk mengikat. ikatan sulfat dan meningkatkan titikdidih karaginan diatas $80^{\circ} \mathrm{C}$. Dengan demikian, ketika suhu perebusan itu mencapai $75^{\circ} \mathrm{C}$ karaginan tidak sampai keluar dari batang rumput laut. Chlorida berfungsi untuk memucatkan rumput laut dalam tungku rebusan. Di sini perlu dilakukan pengamatan seksama, berapa lama perebusan yang optimal (biasanya sekitar 3 jam) agar diperoleh waterge/minimum $100 \mathrm{gr} / \mathrm{cm} 2$ dan viskositas minimum 700 m.Pas

(4) Pencucian : Pencucian dimaksudkan untuk menurunk.an $\mathrm{pH}$ produk clari sekitar 11 menjadi maksimum 9. Pencudan dilakukan diclalam bak pencucian yang dilengkapi dengan kincir air agar air mengalir. Tiap 20 menit air diganti. Air bekas cudan ditampungdi bak limbah cair.

(5) Penjemuran : Produk digelar di atas lantai jemur dengan ketebalan sekitar $5 \mathrm{~cm}$. Penjemuran dilakukan sampaikaclar air sekitar 15\%. Halitu dimaksudkan agar keliga prt1duk dikemas dalam karung kedap udara, kadar air maksimum $16 \%$.

(6) Perajangan(chopping) : Perajangan menggunakan mesin dengan ukuran maksimum $1 \mathrm{~cm}$. Hasil rajangan ditumpuk sesuai bacth produksinya. Dihitung gel strength-nya

\section{Proses Produksi}


(7) Pengujian Mutu : Pengujian mutu dilakukan, k:arena hasil setiap batch proses relatif berbeda. Selanjutnya produk dari bacth satu dan lainnya dicampur dengan tujuan untuk mencapai produk Dengan mutu yang sama. Gel strength minimum adalah $750 \mathrm{gr} / \mathrm{cm} 2$ 8iasanya dibuat campuran agar diperoleh gel strength sekitar $800 \mathrm{gr} / \mathrm{cm} 2$

Pengemasan. Kemasaran adalah karung plastik lapis ganda,dengan lapis primer dari plastik kedap air. Hal ini dimaksudkan untuk mempertahankan kadar air chips, karena Cottonii Chips itu sangat higroskopis. Kemasaan bervolume $25 \mathrm{~kg}$.

\section{Aspek Keuangan}

Rencana Investasi dan Modal Kerja disajikan sebagai berikut :

\begin{tabular}{|c|l|c|c|r|}
\hline No & \multicolumn{1}{|c|}{ Jenis Biaya } & Satuan & Jumlan Fisik & Nilai (Rp) \\
\hline \hline 1 & Investasi Proyek & Paket & 1 & $19,020,819,550$ \\
\hline 2 & Modal kerja Tahun 0 & Paket & 1 & $500,000,000$ \\
\hline 3 & Modal Kerja Tahun 1 (3 bln) & Paket & 1 & $3,488,518,450$ \\
\hline \hline & \multicolumn{5}{|c|}{ Total ... } & $23,009,338,000$ \\
\hline
\end{tabular}

Dalam sentra ini akan beroperasi 8 (delapan) IKM dan ditambah pengolahan ATC Chips pada tahun 1-4 dan Kappa Carrageenan pada tahun kelima dan seterusnya. Adapun IKM yang bergabung dalam sentra ini yaitu :
a. Pomade
e. Nata De Seaweed
b. Hair Tonic
f. Masker Rumla
c. Sunscreen
g. Dodol Rumla
d. Body Lotion
h. Moro Collagen

Kepada seluruh IKM akan melakukan kegiatan bisnisnya pada tempat yang sudah disiapkan di sentra, dan selama 3 tahun seluruh IKM dapat menggunakan fasilitas di sentra tanpa dipungut biaya apapun, dan mulai tahun ke empat dan seterusnya IKM akan dikenakan biaya sewa yang cukup murah yaitu sebesar Rp 2.000.000,sebulan untuk setiap IKM sehingga penerimaan atas sewa alat setahun dapat mencapai $\mathrm{Rp}$ 192.000.000,-.

Selain itu sentra juga melakukan pengolahan sendiri yaitu Alkali Treatment Cottonii (ATC) Chips atau biasa disebut Cottonii
Chips saja. Dengan kapasitas produksi 2.000 $\mathrm{kg} /$ hari, maka dalam satu bulan sebanyak 26 hari kerja akan dihasilkan $19.110 \mathrm{~kg}$ atau 229,32 ton cottonii chips pertahun. Jika harga jual ATC ini sebesar USD 5,2/kg dan kurs USD = Rp 15.000,maka setiap tahun dari tahun 1 s.d tahun ke 4 akan diperoleh penjualan sebesar $\mathrm{Rp}$ 17,891,827,200,-. Sedangkan pada tahun ke-5 dan seterusnya sentra akanmengolah rumput laut menjadi Karaginan murni (Kappa Carrageenan) dengan jumlah bahan baku yang sama dan dengan tingkat rendemen 20\% akan menghasilkan Kappa Karaginan sebanyak 400 $\mathrm{kg} / \mathrm{hari}$ atau 124,8 ton pertahun sebagaimana yang digambarkan pada tabel berikut ini :

Tabel Proyeksi Laba/rugi

\begin{tabular}{|c|c|c|c|}
\hline No & Uraian & Tahun 0 & Tahun 1 \\
\hline \multirow[t]{2}{*}{ 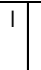 } & Pendapatan & & \\
\hline & Total Pendapatan & $500,000,000$ & $17,891,827,200$ \\
\hline \multirow[t]{4}{*}{$\|$} & Biaya & & \\
\hline & Biaya Investasi (Bangunan \& Peralatan) & $18,270,819,550$ & 0 \\
\hline & Biaya Operasional & & \\
\hline & Total Biaya & $115,580,000$ & $11,270,484,714$ \\
\hline \multirow[t]{2}{*}{ III } & Laba/Rugi Sebelum Pajak & 0 & $6,621,342,486$ \\
\hline & Pajak 25\% & 0 & $1,655,335,621$ \\
\hline IV & Laba/Rugi Bersih & $(17,886,399,550)$ & $4,966,006,864$ \\
\hline V & Profit Margin & 0 & $37.01 \%$ \\
\hline \multirow[t]{3}{*}{ V } & BEP & 0 & \\
\hline & BEP Nilai Penjualan & 0 & $5,653,650,174$ \\
\hline & BEP Produksi (kg) & 0 & 72,483 \\
\hline
\end{tabular}

dari proyeksi laba rugi di atas, usaha ini sudah memberikan laba setelah pajak pada tahun 1 sebesar Rp 4.966.006.864,- atau sebesar 37\% dari total penjualan dengan besaran break event point sebesar Rp 5.653.650.174,- setahun atau setara dengan $72.483 \mathrm{~kg}$ ATC.

Dalam menentukan kelayakan proyek digunakan alat analisis yaitu: Net present value (NPV) dengan tingkat bunga sebagai discount factor sebesar 15\%; Net B/C; IRR; dan Payback Period (PBP). NPV dinyatakan layak apabila > 0; Net B/C dinyatakan layak apabila > 1; IRR dinyatakan layak apabila > discount factor 15\%; dan payback period dibawah 5 tahun.

Perhitungan cashflow selama 5 tahun disajikan pada tabel berikut ini : 


\begin{tabular}{|c|c|c|c|c|}
\hline No & Uraian & Tahun 0 & Tahun 1 & Tahun 2-5 \\
\hline \multicolumn{5}{|c|}{ Inflow } \\
\hline & Total Pendapatan & $500,000,000$ & $17,891,827,200$ & $18,083,827,200$ \\
\hline & Inflow untuk IRR & $500,000,000$ & $17,891,827,200$ & $18,083,827,200$ \\
\hline \multirow[t]{3}{*}{$\|$} & Outflow & & & \\
\hline & Total Biaya & $18,386,399,550$ & $11,706,707,818$ & $11,754,707,818$ \\
\hline & Outflow untuk IRR & $18,386,399,550$ & $11,706,707,818$ & $11,754,707,818$ \\
\hline III & Total Cashflow & & $6,185,119,382$ & $6,329,119,382$ \\
\hline IV & Kumulatif cashflow & $(18,386,399,550)$ & $(12,201,280,168.26)$ & $12,827,197,359$ \\
\hline V & Cashflow untuk IRR & $(18,386,399,550)$ & $6,185,119,382$ & $6,329,119,382$ \\
\hline \multirow[t]{8}{*}{$\mathrm{V}$} & Perhitungan NPV, Net B/C R & & & \\
\hline & IRR,dan PBP & & & \\
\hline & DF $15 \%$ & 1 & 0.870 & 0.497 \\
\hline & & $(18,386,399,550)$ & $(13,008,034,870)$ & $2,501,005,835$ \\
\hline & 1 NPVDF $15 \%$ & $2,501,005,835$ & & \\
\hline & 2 Net B/C ratio DF $15 \%$ & 1.136 & & \\
\hline & 3 IRR & $20.83 \%$ & & \\
\hline & 4 Payback Period (PBP) & 4.18 & Thn & \\
\hline
\end{tabular}

Dari tabel di atas dapat disimpulkan sebagai berikut :

1. NPV DF 15 menghasilkan angka positif sebesar Rp 2.501.005.835,- pada tahun ke 5, karena lebih besar dari 1, maka proyek ini dinyatakan layak untuk dilaksanakan.

2. Net B/C menghasilkan angka 1,136, lebih besar dari 1, maka proyek ini dinyatakan layak untuk dilaksanakan.

3. IRR menghasilkan angka 20,83\%, lebih besar dari discount factor 15\%, maka proyek ini dinyatakan layak untuk dilaksanakan.

4. Payback Period sebagai waktu pengembalian investasi selama 4,18 tahun atau di bawah 5 tahun, maka proyek ini dinyatakan layak untuk dilaksanakan.

Dari empat alat analisis tersebut semuanya memenuhi kriteria, maka berdasarkan alat analisis tersebut, maka proyek pengembangan industri rumput laut di kecamatan moro kabupaten karimun layak untuk dilaksanakan.

\section{Analisis Sensitivitas}

Dalam analisis proyek penerimaan dan biaya, didasarkan pada sumsi dan proyeksi yang memiliki ketidakpastian, sehingga diperlukan analisis sensitivitas untuk menguji seberapa jauh proyek yang dilaksanakan sensitif terhadap perubahan dari harga-harga input maupun output, kesalahan dalam pembangunan sarana fisik dan operasional ataupun kelemahan estimasi produksi dan pamasaran. Dalam pola pembiayaan ini analisis sensitivitas menggunakan 3 skenario

\section{Skenario I}

Pendapatan mengalami penurunan sedangkan biaya investasi maupun biaya operasional tetap (konstan). Penurunan pendapatan dapat saja terjadi karena permintaan pasar mengalami penurunan atau jumlah produksi tidak tercapai dengan berbagai penyebabnya, seperti kegagalan panen rumput laut atau kerusakan mesin pengolahan dan sebagainya.

\begin{tabular}{|c|l|c|c|}
\hline \multirow{2}{*}{ No } & \multirow{2}{*}{ Kriteria Kelayakan } & \multicolumn{2}{|c|}{ Penerimaan Turun } \\
\cline { 3 - 4 } & & $9 \%$ & $10 \%$ \\
\hline \hline 1 & Net B/C Ratio DF 15 & 1.037 & 0.99 \\
\hline 2 & NPV DF 15 & Rp676,224,084 & (Rp2,016,934.50) \\
\hline 3 & IRR & $15,62 \%$ & $12,3 \%$ \\
\hline 4 & PBP & 4,8 Tahun & 5 Tahun \\
\hline
\end{tabular}

Dari tabel tersebut tergambar dengan jelas bahwa pada skenario I, pada saat pendapatan turun sebesar $9 \%$ dengan tingkat bunga $15 \%$ net $\mathrm{B} / \mathrm{C}$ ratio dan NPV positif dan IRR mencapai $15.62 \%$ dan proyek tersebut layak untuk dilaksanakan, namun apabila pendapatan menurun sampai $10 \%$ maka proyek tidak layak untuk diteruskan, karena IRR 12,3\% (proyek di bawah suku bunga 15\%) dan NPV negatif.

\section{Skenario II}

Biaya operasional mengalami kenaikan sedangkan biaya investasi dianggap tetap. Kenaikan biaya operasional ini dapat saja terjadi apabila harga input meningkat. Dalam hal ini komponen terbesar adalah bahan baku. Maka biaya operasi sensitif terhadap kenaikan bahan baku, bahan penolong dan bahan laboratorium.

\begin{tabular}{|c|l|c|c|}
\hline \multirow{2}{*}{ No } & \multirow{2}{*}{ Kriteria Kelayakan } & \multicolumn{2}{|c|}{ Biaya Naik } \\
\cline { 3 - 4 } & & $15 \%$ & $16 \%$ \\
\hline \hline 1 & Net B/C Ratio DF 15 & 1.017 & 0.997 \\
\hline 2 & NPV DF 15 & Rp312,724,940 & $($ Rp62,420,666.80) \\
\hline 3 & RR & $15,95 \%$ & $11,7 \%$ \\
\hline 4 & PBP & 4,9 Tahun & 5,02 Tahun \\
\hline
\end{tabular}

Dari tabel skenario II, pada saat biaya naik sebesar $15 \%$ dengan tingkat bunga $15 \%$ net $\mathrm{B} / \mathrm{C}$ ratio dan NPV positif dan IRR mencapai 15,95\% dan proyek tersebut layak untuk dilaksanakan, namun apabila pendapatan menurun sampai $16 \%$ maka proyek tidak layak untuk diteruskan, karena IRR 11,7\% (proyek di bawah suku bunga 15\%) dan NPV negative, PBP di atas 5 tahun

\section{Skenario III}

Skenario ini merupakan gabungan dari skenario I dan II yaitu diasumsikan pendapatan menurun 
dan pada saat yang sama biaya operasional mengalami kenaikan, sedangkan biaya investasi dianggap konstan. Hasil analisis terhadap ketiga skenario tersebut di atas dapat dilihat dalam tabel berikut :

\begin{tabular}{|c|l|c|c|}
\hline \multirow{2}{*}{ No } & \multirow{2}{*}{ Kriteria Kelayakan } & \multicolumn{2}{|c|}{ Penerimaan Turun dan Biaya Naik } \\
\cline { 3 - 4 } & & $5 \%$ & $6 \%$ \\
\hline \hline 1 & Net B/C Ratio DF 15 & 1.020 & 0.963 \\
\hline 2 & NPV DF 15 & Rp369,880,508 & (Rp683,506,117.06) \\
\hline 3 & IRR & $15,2 \%$ & $11,8 \%$ \\
\hline 4 & PBP & 4,8 Tahun & 5,3 Tahun \\
\hline
\end{tabular}

Hasil analisis skenario III dengan asumsi terjadi penurunan pendapatan dan kenaikan biaya operasi. Pada saat mengalami kenaikan dan penurunan $5 \%$ proyek tersebut masih layak untuk dilaksanakan, karena pada saat suku bunga 15\% Net B/C ratio lebih dari satu dan NPV positif serta IRR mencapai $15.20 \%$. Namun pada saat penerimaan turun dan biaya naik sebesar 6\% proyek ini tidak layak dilaksanakan karena IRR lebih kecil dari suku bunga yaitu 11.8\%,d an PBP di atas 5 tahun

\section{Analisis Manfaat Ekonomi}

Pembangunan Sentra IKM ini diharapkan memberikan manfaat secara ekonomi pada nelayan budi daya, masyarakat umum, para pengusaha serta Pemerintah Daerah. Manfaat ekonomi yang diperoleh ini akan berbeda-beda, hal ini tergantung dari kontribusi yang diberikan dalam pengembangan Sentra IKM. Manfaat ekonomi yang pertama tentu harus dirasakan oleh nelayan budi daya yang saat dengan jumlah sekitar 393 KK. Hal ini diperoleh karena terserapnya hasil budi daya rumput laut. Pada Sentra Industri Kecil Menengah ini, Nelayan budi daya bisa langsung menjual hasil panen mereka atau menjual dalam bentuk kering secara langsung ke sentra IKM sehingga nelayan budi daya mendapatkan hasil dari panen mereka secara langsung karena sifat transaksi adalah cash and carry. Pembangunan Sentra IKM ini juga memberikan manfaat pada masyarakat di sekitar Sentra dengan banyak terbukanya lapangan pekerjaan, mulai dari lapangan pekerjaan pada saat pembangunan Sentra sampai pada saat Sentra sudah beroperasi penuh.
Untuk pembangunan Sentra IKM ini diperkirakan akan menyerap tenaga kerja lokal sebanyak 100 orang, sedangkan untuk operasional Sentra IKM akan menyerap tenaga kerja lebihd ari 50 orang. Pada saat Sentra IKM sudah beroperasi penuh maka para pelaku IKM dapat melakukan pemasaran dan penjualan hasil olahan melalui Sentra IKM.

Pemerintah Kabupaten Karimun juga akan memperoleh manfaat ekonomi dari Sentra IKM berupa keuntungan dari operasional Sentra IKM yang diproyeksikan akan BEP pada tahun ke-4 bulan ke-2.Hal ini tentu saja bisa menambah PAD dan meningkatkan perekonomian dengan bertambah banyaknya perputaran uang dari kegiatan ekonomi berbasis rumput laut.

\section{Kesimpulan}

\section{Kesimpulan}

a) NPV DF 15 menghasilkan angka positif sebesar Rp 2.501.005.835,- pada tahun ke 5, karena lebih besar dari 1, maka proyek ini dinyatakan layak untuk dilaksanakan.

b) Net B/C menghasilkan angka 1,136, lebih besar dari 1, maka proyek ini dinyatakan layak untuk dilaksanakan.

c) IRR menghasilkan angka $20,83 \%$, lebih besar dari discount factor 15\%, maka proyek ini dinyatakan layak untuk dilaksanakan.

d) Payback Period sebagai waktu pengembalian investasi selama 4,18 tahun atau di bawah 5 tahun, maka proyek ini dinyatakan layak untuk dilaksanakan.

Dari empat alat analisis tersebut semuanya memenuhi kriteria, maka berdasarkan alat analisis tersebut, maka proyek pengembangan industri rumput laut di kecamatan moro kabupaten karimun layak untuk dilaksanakan.

e) Dengan menggunakan analisis sensitivitas pada skenario I, pada saat pendapatan turun sebesar 9\% dengan tingkat bunga 15\% net $\mathrm{B} / \mathrm{C}$ ratio dan NPV positif dan IRR mencapai $15.62 \%$ dan proyek tersebut layak untuk dilaksanakan, namun apabila pendapatan menurun sampai $10 \%$ maka proyek tidak layak untuk diteruskan, karena IRR 12,3\% 
(proyek di bawah suku bunga 15\%) dan NPV negatif.

f) Pada skenario II saat biaya naik sebesar $15 \%$ dengan tingkat bunga $15 \%$ net $\mathrm{B} / \mathrm{C}$ ratio dan NPV positif dan IRR mencapai $15,95 \%$ dan proyek tersebut layak untuk dilaksanakan, namun apabila pendapatan menurun sampai $16 \%$ maka proyek tidak layak untuk diteruskan, karena IRR 11,7\% (proyek di bawah suku bunga 15\%) dan NPV negative, PBP di atas 5 tahun.

g) Hasil analisis skenario III dengan asumsi terjadi penurunan pendapatan dan kenaikan biaya operasi. Pada saat mengalami kenaikan dan penurunan $5 \%$ proyek tersebut masih layak untuk dilaksanakan, karena pada saat suku bunga $15 \% \mathrm{Net} B / \mathrm{C}$ ratio lebih dari satu dan NPV positif serta IRR mencapai $15.20 \%$. Namun pada saat penerimaan turun dan biaya naik sebesar $6 \%$ proyek ini tidak layak dilaksanakan karena IRR lebih kecil dari suku bunga yaitu $11.8 \%$,d an PBP di atas 5 tahun

\section{Saran}

1. Mendorong pembangunan Sentra IKM rumput laut di Kabupaten Karimun akan memberikan dampak berkembangnya industri-industri lain yang berbasis rumput laut sejalan dengan banyaknya turunan hilirisasi dari rumput laut ini, dan apabila sentra IKM rumput laut ini dikawal dan dikelola dengan baik akan menumbuhkan kekuatan ekonomi baru di Provinsi Kepulauan Riau.

2. Untuk penguatan posisi penawaran para pembudi daya, maka disarankan agar pemerintah daerah melakukan pengawasan agar terjadinya perniagaan yang adil (fair trade). Hal ini diperlukan agar tidak merugikan petani budi daya, dan akan menjadi sumber penerimaan keluarga dalam jangka panjang, dan secara global diperlukan untuk mempertahankan posisi Indonesia yang menjadi pemimpin pasar rumput laut kering.

3. Dalam pengelolaan sentra IKM rumput laut ini, dari 3 bentuk kelembagaan yang dapat dibentuk, lebih disarankan pengelolaan sentra ini adalah BUMD dengan pertimbangan adalah tugas dan tanggung jawab pengelola sentra IKM cukup besar dan memerlukan professional yang tinggi di mana tugas utamanya sebagai fasilitator bagi pelaku IKM di sentra juga tugas sebagai pengelola harus mendapatkan pendapatan atau laba yang berguna bagi kelangsungan sentra IKM ini.

4. Dengan dibentuknya sentra IKM rumput laut ini, yang tentunya memerlukan sumber daya manusia yang professional dalam pengelolaannya dan berdaya saing, maka penyelenggara pendidikan terutama pendidikan kejuruan agar lebih memfokuskan kurikulum pada sumber daya alam kemaritiman terutama pada rumput laut. Begitu pula dengan pendidikan tinggi agar lebih banyak dan intens melakukan penelitian terkait dengan meningkatkan sumber daya alam rumput laut, baik dalam pencarian bibit unggul maupun dalam hal pengolahan hasilnya.

\section{Daftar Pustaka}

Chopra S dan Meindl P.2004.Supply Chain Management: Strategy,Planning, and Operation.Third Edition.New Jersey (USA): Pearson Education, Inc.

Farida, I. 2002. Pengaruh Pengeringan Terhadap Sifat Fisik dan Kimia Dodol Rumput Laut. Skripsi. Institut Pertanian Bogor

Jackson A, Harjanti D. 2015. Evaluasi dan Perancangan Model Bisnis pada Kaisar Organizer Dengan Business Model Canvas. AGORA [internet]. [diunduh pada 2018 September 21]; 3(2): 302-305. Tersedia $\mathrm{pd}$ http://studentjournal.petra.ac.id/index.php/ manajemenbisnis/ issue/view/162.

Kemala, R. 2002. Penggunaan Natrium Benzoat untuk Memperpanjang Daya Awet Dodol Rumput Laut. Skripsi. Bogor. Institut Pertanian Bogor. 
Jurnal Bahtera Inovasi Vol. 3 No. 1 Tahun 2019

Marpaung, P. 2001. Pengaruh Konsentrasi Gula Pasir Terhadap Mutu Dodol Rumput Laut. Skripsi. Bogor. Institut Pertanian Bogor.

McHugh, D. J. (2003). A guide to the seaweed industry: FAO fisheries technical paper No. 441 (pp. 61-72). Rome: FAO.

Nurlela. 2001. Pengaruh Konsentrasi Gula Terhadap Mutu Dodol Rumput Laut .Skripsi. Bogor. Institut Pertanian Bogor.

Osterwalder A, Pigneur Y. 2012. Business Model Generation. Jakarta (ID): PT Elex Media Komputindo.

Suheti, E. 2000. Pengaruh Penambahan KL Terhadap Mutu Dodol Rumput Laut. Skripsi. Bogor. Institut Pertanian Bogor.

Suriaty. 2002. Pengaruh Penambahan Santan Kelapa Terhadap Mutu Dodol Rumput Laut Jenis Eucheuma cottonii. Skripsi. Institut Pertanian Bogor

Simchi-Levi D, Kaminsky P. dan Simchi-Levi E. 2008. Designing And Managing The Supply Chain: Concepts, Strategies, and Case Studies. New York (USA) : Mc Graw Hill3rd ed, New York. 